\title{
THE CONSTITUTIONAL RIGHTS OF CHILDREN TO BODILY INTEGRITY AND AUTONOMY
}

\author{
Emma du Plessis \\ LLB LLM
}

Glynis van der Walt

BJuris LLB LLM

Senior lecturer, Nelson Mandela Metropolitan

University, Port Elizabeth

Avinash Govindjee

BA LLB LLM LLD

Professor, Nelson Mandela Metropolitan

University, Port Elizabeth

\section{SUMMARY}

This is the first of two articles focusing on the development and consequence of children's constitutional rights to bodily integrity and autonomy, as expressed in South African legislation. While this particular contribution evaluates the core constitutional rights at play and analyses key legislative provisions giving effect to these rights in South Africa, the contribution which follows tackles a more specific issue: the inadequate regulation of the legal position of "saviour sibling" and "benefactor children" in South African law.

\section{$1 \quad$ INTRODUCTION}

The Constitution of the Republic of South Africa, 1996 ("the Constitution") represents a dramatic breakthrough in the realisation of human rights for South Africans of all ages, classes and colours. ${ }^{1}$ With the dawning of the Constitution came recognition and respect for a particularly vulnerable, and often ignored, group in society, namely children. This is the first of two articles paying particular attention to the development and consequence of

\footnotetext{
This article is based, in part, on the LLM Dissertation of E du Plessis.

Shabalala v Attorney General of the Transvaal 1996 (1) SA 725 (CC) par 26, echoing the words of Mahomed J in S v Mhlungu 1995 (3) SA 391 (CC).
} 
children's constitutional rights to bodily integrity and autonomy as expressed through South African legislation. ${ }^{2}$ This contribution evaluates two particular constitutional rights in respect of children and includes an analysis of key legislative provisions giving effect to these rights in South Africa. This survey of present South African law raises the issue of "saviour siblings" and "benefactor children", and the inadequate regulation of the legal position of these categories of children in the country. This is an issue tackled directly in the contribution which follows.

\section{THE RIGHTS IN THE BILL OF RIGHTS RELATING TO CHILDREN}

"Constitutional rights do not mature and come into being magically only when one attains the [S]tate-defined age of majority. Minors, as well as adults, are protected by the Constitution and possess constitutional rights." ${ }^{3}$

According to section 7(1) of the Constitution, both adults and children alike are bearers of rights. ${ }^{4}$ Since children are viewed as the most vulnerable members of South Africa's society, ${ }^{5}$ section 28 of the Constitution has been included to provide particular protection and rights for children in situations where they are considered to be particularly vulnerable. ${ }^{6}$ A common misconception that often accompanies a discussion of section 28 is that these are the only rights afforded to children in the entire Constitution, perhaps because section 28 is headed "Children". While it is true that the rights in section 28 apply exclusively to children, this does not bar children from the enjoyment, protection and application of other human rights found within the Bill of Rights.

\section{S 12(2) of the Constitution.}

Planned Parenthood v Danforth 428 US 52 (1976), quoted in Human Die Invloed van die Begrip Kinderregte op die Privaatregtelike Ouer-kind Verhouding in die Suid-Afrikaanse Reg Unpublished LLD Dissertation University of Stellenbosch (1998) 78 in Currie and De Waal Bill of Rights 5ed (2005) 600 .

$4 \quad S 7(1)$ states "This Bill of Rights is a cornerstone of democracy in South Africa. It enshrines the rights of all people in our country and affirms the democratic values of human dignity, equality and freedom."

5 Malherbe Legal Issues Arising from the Medical Use of Blood on Children of Jehovah's Witnesses (LLB Treatise, NMMU, 2007) 30; and Van der Walt "The United Nations Convention on the Rights of the Child - Has the Bridge been Crossed between Theory and Practice: Mauritius and South Africa?" 2010 Obiter 715.

6 Currie and De Waal Bill of Rights 603. This chapter was revised by Elsje Bonthuys, Associate Professor of Law, University of Witwatersrand, for this particular edition (fifth edition) of The Bill of Rights Handbook. The inclusion of $\mathbf{s} 28$ in the Constitution reflects South Africa's commitment to developing a children's right orientated culture and enshrines the principles of both the United Nations Convention on the Rights of the Child (UNCRC) and the African Charter on the Rights and Welfare of the Child (ACRWC) in domestic law. Kassan How Can the Voice of the Child be Adequately Heard in Family Law Proceedings? (LLM Mini treatise, UWC, 2004) 35.

7 Skelton and Proudlock "Interpretation, Objects, Application and Implementation of the Children's Act" in Davel and Skelton (eds) Commentary on the Children's Act (2007) 1-7. See also Kruger "The Protection of Children's Rights in the South African Constitution: Reflections on the First Decade" 2007 THRHR 239 241. See Devenish The South African Constitution (2005) 140; and Heaton SA Family Law 3ed (2010) 271. See too Bhe v 
Many of the rights which are found in section 28 are, in fact, mere repetitions of the rights found in the other sections of the Bill of Rights, and can therefore be classed as background rights to the specific rights of children. ${ }^{8}$ An important observation, however, is that while not all rights are repeated in section 28, they nevertheless remain important for children. These rights include: the rights to equality, ${ }^{9}$ dignity, ${ }^{10}$ bodily and psychological integrity ${ }^{11}$ and the right to individual autonomy. ${ }^{12}$ It is the lastmentioned two rights, which are of particular importance to the topic of this article, which require detailed discussion.

\section{Children's rights to bodily integrity}

As bearers of rights, children have the right to bodily and psychological integrity, which is found under the protection of the so-called "umbrella right" of freedom and security of the person in section 12 of the Constitution. ${ }^{13}$ The right to bodily integrity specifically comprises: ${ }^{14}$

"[The right] (a) to make decisions concerning reproduction;

(b) to security in and control over their body; and

(c) not to be subjected to medical or scientific experiments without their informed consent."

The first component of section 12(2) is the right to make decisions concerning reproduction. ${ }^{15}$ This right recognises that the ability to make decisions relating to reproduction is a crucial aspect of bodily control, and covers matters pertaining to abortion and sterilisation. ${ }^{16}$

Magistrate, Khayelitsha (Commission for Gender Equality as Amicus Curiae); Shibi v Sithole; South African Human Rights Commission v President of South Africa 2005 (1) SA 580 (CC) par 52. Langa DCJ in his judgment stated that "not only those rights expressly conferred by $\mathrm{s} 28$ but also all the other rights in the Constitution which, appropriately construed, are also conferred upon children".

8 Kruger 2007 THRHR 241.

9 S 9 of the Constitution.

$\mathrm{S} 10$ of the Constitution.

S 12(2) of the Constitution.

12 The right to autonomy is constructed from the rights to privacy, freedom of religion, freedom of expression and freedom of association read together. Kruger 2007 THRHR 241; Bekink and Brand "Constitutional Protection of Children" in Davel (ed) Introduction to Child Law in South Africa (2000) 169-178.

13 See s 12(1) and (2) of the Constitution. This supports the viewpoint that $s$ 12(2) recognises at a minimum, that each body is equal in worth and is entitled to equal respect. See Woolman "Dignity" in Woolman and Bishop (eds) Constitutional Law of South Africa Volume 3 2ed (2008) 36-10.

14 S 12(2) of the Constitution.

15 S 27(1)(a) of the Constitution also recognises the right to reproductive health care. See the argument put forward in Bishop and Woolman "Freedom and Security of the Person" in Woolman and Bishop (eds) Constitutional Law of South Africa Volume 3 2ed (2008), as to why the right to reproduction is mentioned in s 27 as well.

16 Currie and De Waal Bill of Rights 308. See further the Choice on Termination of Pregnancy Act 92 of 1996 and the Sterilisation Act 44 of 1998. See also Re: Angela 2010 FamCA 98 (16 February 2010). This is an Australian case, where the court had to decide whether it would be in the best interest of the child for her to undergo sterilisation. At the time, the young girl was eleven years old and suffered from Retts syndrome ("a neurodevelopmental 
The second component of section 12(2) is the right to security in and control over the body. ${ }^{17}$ The wording of section 12(2)(b) assumes that individuals are capable of taking decisions that are, at the very least, in their own interests. Linked to this component of the right, it is often argued that interference and intervention in the lives of others must, in general, be minimised. This implies that, while a person may experience and express genuine concern for the well-being of another, the choices made by the other person, with respect to issues relating to bodily integrity, must ultimately be respected. ${ }^{18}$

The final component of section 12(2) is the right not to be subjected to medical or scientific experimentation without informed consent. Despite some uncertainty regarding what amounts to medical and scientific experimentation, it is commonly accepted that a medical practitioner has a duty to inform his or her patient as to the risks of the procedure to be performed so that the patient may give an informed consent. ${ }^{19} \mathrm{~A}$ patient is regarded as having given informed consent to medical and scientific experiments if he or she is not merely informed of the salient risks and options, but actually appreciates and understands the purpose of the experiment itself. ${ }^{20}$

disorder that affects girls almost exclusively. It is characterized by normal early growth and development followed by a slowing of development, loss of purposeful use of the hands, distinctive hand movements, slowed brain and head growth, problems with walking, seizures, and intellectual disability") and epileptic seizures. It was noted that the epileptic seizures grew significantly stronger at the time of the young girl's menstrual cycle. In view of this, the court was asked to decide whether it would be in the best interests of the young girl to be sterilised as a means to regulate the intensity of her seizures and to alleviate her suffering. After considering all the relevant facts before it, the court held that it would be in the best interests of the young girl if she were sterilised. See National Institute of Neurological Disorders and Stroke "Rett Syndrome Fact Sheet" http://www.ninds.nih.gov/ disorders/rett/detail rett.htm (accessed on 2010-03-16). With regards to abortion, Christian Lawyers Association of South Africa v Minister of Health 1998 (4) SA 1113 (T) held that a foetus does not enjoy the protection of the provisions of the Constitution and, for this reason, $s 12$ would not be limited by any interests relating to a foetus.

17 "Security in" implies "the protection of bodily integrity against physical invasions by the State and others": see Minister of Safety and Security v Xaba 2004 (1) SACR 149 (D) for an example of this type of security. "Control over", on the other hand, "guarantees the freedom to exercise autonomy or the right to self-determination with respect to the use of one's body": see Bishop and Woolman in Woolman and Bishop (eds) Constitutional Law of South Africa Volume 3 40-85.

18 Bishop and Woolman in Woolman and Bishop (eds) Constitutional Law of South Africa Volume 3 40-85. As Sachs and O'Regan JJ noted in S v Jordan 2002 (6) SA 642 (CC), "[the body is not] something to be commodified. Our Constitution requires that it be respected" (par 74).

19 S 6(1)(c) and (d) of the National Health Act 61 of 2003.

20 C v Minister of Correctional Services 1996 (4) SA 292 (C) as quoted in Bishop and Woolman in Woolman and Bishop (eds) Constitutional Law of South Africa Volume 3 40-96. In the same vein, Mojapelo J in Christian Lawyers Association 2005 (1) SA 509 (T) stated that informed consent in South African law rests on the three independent legs of knowledge, appreciation and consent. 


\section{Children's rights to autonomy}

Working hand-in-hand with the right to bodily integrity is the contentious right of autonomy or self-government/self-determination. This refers to the right that a person has to decide what they want to be done with their body, without anybody else deciding such matters for them. ${ }^{21}$ Despite not being found within a particular section of the Constitution, it is arguable that the right to autonomy is comprised of the rights to privacy, freedom of religion, belief and opinion, freedom of expression and freedom of association, all of which are rights that are guaranteed to children. ${ }^{22}$

Support for a child's right to autonomy can be found in the work of several authors. Freeman, for example, proposes four categories of rights for children, of which the third and fourth categories respectively validate a child's right to autonomy.

The right to be treated as an adult is the third of Freeman's categories and proposes that the rights and liberties which are extended to adults should also be extended to children. ${ }^{23}$ Based on the research of developmental psychologists, Freeman argues that the age-related restrictions placed on children should be constantly reviewed, alternatively that the legal capacity of children to make decisions should be determined on a case-by-case basis, given that maturity levels differ amongst children, irrespective of their age. $^{24}$

Freeman's fourth category of children's rights is rights against parents. It is this component of the right which would, for example, allow for claims of independence from parental control before the age of majority being reached. ${ }^{25}$ These rights against parents would also, for example, sanction a child's decision-making powers in matters such as hair length, curfew, body piercing, use of contraception, choice of termination of pregnancy,

21 Autonomy originates from Greek, with "auto" meaning self and "nomos" meaning law. The combination of the words results in the definition "to be one's own law". Jordaan "Autonomy as an Element of Human Dignity in South African Case Law" 2009 (9) Journal of Philosophy, Science and Law 14 . It must be mentioned that autonomy overlaps with freedom. Freedom is composed of political and individual or personal freedom. When the overlap occurs, it is generally assumed that autonomy overlaps personal freedom. Jordaan 2009 (9) Journal of Philosophy, Science and Law 4. The Collins Shorter English Dictionary defines autonomy as the "freedom to determine one's own actions, behaviour, etc." Collins Shorter English Dictionary 71.

22 It has been held that the concept of an open society suggests autonomy and, since an open society is a core concept of the Constitution, autonomy is established as a general value of the Constitution. Furthermore in NM v Smith 2007 (5) SA 250 (CC) par 145-146 O'Regan J suggested autonomy as a constitutional value that underlies human dignity, freedom and privacy. Jordaan 2009 (9) Journal of Philosophy, Science and Law 6.

23 See Freeman The Rights and Wrongs of Children (1983) 22-23 as referred to in Human "The Theory of Children's Rights" in Davel (ed) Introduction to Child Law in SA (2000) 157158.

24 This would clearly require the use of an objective test: See further, Freeman The Rights and Wrongs of Children 46 as referred to in Human in Davel (ed) Introduction to Child Law in $S A$. For further criticism of existing age-based assumptions relating to children's capacity, see Wald "Children's Rights: A Analysis" 1979 University of California Davis LR 255266 268 as referred to by Human in Davel Introduction to Child Law in SA 161.

25 Freeman The Rights and Wrongs of Children 48. 
determining gender orientation and consent to medical treatment and procedures.

The right to autonomy ensures that children enjoy a level of independence from their parents. Protecting and recognising the autonomy and integrity of a child, including the child's decision-making capabilities, does not detract from the risks associated with complete emancipation of children. These risks include the dangers of foisting on a child an unrealistic expectation to always act in a mature and responsible fashion when making decisions. It must be acknowledged that children frequently do not have the emotional or experiential capacity to make proper decisions at a young age. Society must, in sum, be careful not to dichotomize a child's right to autonomy. ${ }^{26}$ Complete support for nurturance, at the cost of self-determination, and vice versa, must be carefully avoided.

\section{SOUTH AFRICAN LEGISLATION}

While acknowledging that the Constitution remains the supreme law of the land, ${ }^{27}$ and therefore, the ultimate reference point for South Africa's society as a whole, there exist statutes that are specific to, amongst others, children and health in South Africa. These statutes provide additional protection of rights and support and supplement the constitutional provisions. ${ }^{28}$ Of particular importance to this contribution are the Children's Act, ${ }^{29}$ Choice on Termination of Pregnancy Act (CoToPA) ${ }^{30}$ and the National Health Act (hereinafter "NHA"). ${ }^{31}$ Each of these statutes impacts upon children, parents, the State and the medical profession in some or other way.

The discussion that follows will concentrate on how the various relevant pieces of legislation make provision for a child's participation in matters relating to his or her health and welfare. It will also be determined if these statutes demonstrate adequate respect for a child's right to bodily integrity and autonomy.

\section{Children's Act $^{32}$}

Following the adoption of the Constitution, many of the pre-existing statutes had to be rewritten and reworded. ${ }^{33}$ One statute, which underwent this

26 See Freeman "Taking Children's Rights more Seriously" in Alston, Parker and Seymour (eds) Children, Rights and the Law 66.

27 S 2 of the Constitution.

28 See s 8(1) of the Children's Act which states "[t]he rights which a child has in terms of this Act supplement the rights which a child has in terms of the Bill of Rights." See further SA Law Commission Review of the Child Care Act Project 110 Report (2002) 16 par 3.4; and McQuoid-Mason "Health Law - The Basics" in Dhai and McQuoid-Mason (eds) Bioethics, Human Rights and Health Law: Principles and Practice (2011) 48.

2938 of 2005.

92 of 1996 .

61 of 2003.

32 Apart from the provisions already operational from 2007, the Children's Act 38 of 2005 took effect in its entirety from 1 April 2010. 
procedure (in 1997) was the Child Care Act. $^{34}$ The redrafting procedure commenced following the recommendations of then Minister of Welfare and Population Development, Geraldine Fraser-Moleketi. These recommendations resulted in the Minister of Justice and Constitutional Development requesting the South African Law Commission (hereinafter "the SALC") to include a review of child-care legislation into the programme of the SALC. ${ }^{35}$ The Commission interpreted the mandate that it was given broadly, and consequently sought to use the constitutional, regional and international-law imperatives to draft a new and more comprehensive statute that would promote and protect children's rights. ${ }^{36}$ The results of this interpretation lead to the promulgation of the Children's Act 38 of $2005 .^{37}$

The aims of the Children's Act, as set out in the long title are, inter alia, to supplement and give effect to certain rights which a child has in the Bill of Rights, and to set out principles relating to the care and protection of children. ${ }^{38}$ Added to this, the Children's Act also aims to provide children with special protective measures not necessarily provided for in the long title of the Act or the Bill of Rights. ${ }^{39}$ In short, the provisions of the Children's Act aim to provide South Africa's children with the necessary protection and safeguards that will ensure that their constitutional rights are being upheld, and that their overall well-being and protection is being promoted as well.

To this end, the discussion that appears below (on the Children's Act) is restricted to the provisions that have bearing on a child's right to bodily integrity and autonomy and/or relate to medical treatment.

33 Skelton and Proudlock in Davel and Skelton (eds) Commentary on the Children's Act 1-10$1-11$.

34 Act 74 of 1983.

35 SA Law Commission Review of the Child Care Act Project 110 Discussion Paper 103 (2002) 2. The SALC was renamed and is now known as the South African Law Reform Commission. See further Skelton and Proudlock in Davel and Skelton (eds) Commentary on the Children's Act 1-12.

36 Skelton and Proudlock in Davel and Skelton (eds) Commentary on the Children's Act 1-12.

37 The Children's Act was partially operational from 2007 but became fully operational from 1 April 2010, thereby repealing the Child Care Act 74 of 1983 in its entirety.

38 See the long title of both the Children's Act and the Children's Amendment Act 41 of 2007. See further s 8(1) of the Children's Act and Kassan and Mahery "Special Child Protective Measures in the Children's Act" in Boezaart (ed) Child Law in South Africa (2009) 185. The SALC went to great lengths to ensure that only supplementary rights were included in the Children's Act and that none of the provisions were repetitions or duplicates of existing rights in the Bill of Rights. See Review of the Child Care Act Discussion Paper 10388.

39 The special protective measures include the protection against social, cultural and religious practices which are detrimental to the well-being of the child (s 12). Also included under this heading are the protective measures relating to the trafficking of children (ss 281-291) and to the health of children, particularly focusing on the child's right to consent to medical treatment, operations, HIV testing and contraceptives (ss 129, 130 and 134). 


\section{General principles and special protective measures of the Children's Act as they relate to the health of children ${ }^{40}$}

By now it has been determined that children have the right to bodily integrity and autonomy, which in the simplest of terms means that a child has the right to determine what happens to his or her body (self-determination). ${ }^{41}$ Therefore, before anything is done to the body of a child, his or her consent is theoretically required. ${ }^{42}$ Without this consent, any contact with a child's body could potentially amount to assault. ${ }^{43}$ For purposes of medical treatment and surgical operations, children are considered to have the capacity to consent if they comply with two requirements, namely, age (twelve years and above) and maturity. ${ }^{44}$ Therefore, despite a child being vested with the rights to bodily integrity and autonomy, children are generally regarded as lacking the necessary capacity to make decisions regarding their medical care before the age of twelve.

Section 129(4) of the Children's Act provides:

"The parent, guardian or care-giver of a child may, subject to section 31 , consent to the medical treatment of the child if the child is -

(a) under the age of 12 years; or

(b) over that age but is of insufficient maturity or is unable to understand the benefits, risks and social implications of the treatment."

Whereas section 129(4) of the Children's Act makes provision for medical treatment, section 129(5) of the Children's Act relates to consent for surgical operations on children. Section 129(5) provides:

"The parent or guardian of a child may, subject to section 31, consent to a surgical operation on the child if the child is -

(a) under the age of 12 years; or,

(b) over that age but is of insufficient maturity or is unable to understand the benefits, risks and social implications of the operation."

40 Throughout this research, it has become apparent that, despite having rights, there are no provisions in the Children's Act which alert parents and children to these rights. Therefore, it must be asked how children and parents become aware of these rights. Does the medical profession bear the onus to inform both child and parent of the rights in s 129 or is this the government's responsibility?

41 See $\mathrm{s}$ 12(2)(a)-(c) of the Constitution.

42 See Castell v De Greef 1994 (4) SA 408 (C).

43 Sloth-Nielsen "Protection of Children" in Davel and Skelton (eds) Commentary on the Children's Act 2ed (2010) 7-28.

44 Kassan and Mahery in Boezaart (ed) Child Law in South Africa 208-209.

45 A child is also regarded as lacking the necessary capacity to consent if that child is over the age of twelve, but is not mature enough or is subsequently unable to understand the benefits and risks of the medical treatment or surgery he or she is to undergo. Prior to the enactment of the Children's Act, the Child Care Act 74 of 1983 was the authoritative statute on children and it held that the age of consent was fourteen years for medical treatment and eighteen years for surgical operations respectively. See s 39(4) of the Child Care Act. One exception to this statement is the right to consent to the termination of a pregnancy, as will be seen in the discussion below. 
In both section 129(4) and (5), a child under the age of twelve is considered to lack the necessary capacity to consent to treatment or surgery. In these circumstances, a parent or guardian may consent to the treatment or surgery of the child in question when they believe this to be in the best interests of the child. ${ }^{46}$ Although not stated, it can be inferred that, while a parent may consent, they are equally entitled to refuse treatment or surgery, if they believe it not to be in the best interests of the child. While parents and guardians have the right to refuse treatment, health-care professionals are not bound by this refusal, and may approach the court asking for a ruling to be made on the matter. ${ }^{4}$

The right to consent that a parent or guardian is afforded in section 129(4) and $(5)$ is subject to the condition stipulated in section 31 of the Children's Act. $^{48}$ The condition is that the views and wishes of the child in question must be given due consideration ${ }^{49}$ before any decision, which is likely to change significantly, or have an adverse effect on a child's health, is made. ${ }^{50}$

The fact that the views of a child must be given due consideration can be said to stem from a child's right to participate, as provided by section 10 of the Children's Act. ${ }^{51}$ Section 10 states:

"[e]very child that is of such an age, maturity and stage of development as to be able to participate in any matter concerning that child has the right to participate in an appropriate way and views expressed by the child must be given due consideration."

The use of the words "any matter" makes allowance for a child to participate in matters affecting his or her health. ${ }^{52}$

46 Refer to the Health Care Professions Council of South Africa Guidelines for Good Practice in the Healthcare Professions Seeking Patients' Informed Consent: The Ethical Considerations Booklet 9 (2008) 9 www.hpcsa.co.za/downloads/conduct_ethics/rules/ generic_ethical_rules/booklet_9_informed_consent.pdf (accessed on 2011-11-19).

47 See also Hay v B 2003 (3) SA 492 (W).

48 Kassan and Mahery in Boezaart (ed) Child Law in South Africa 215.

49 S 31(1)(a) and (b)(iv) of the Children's Act.

50 In that a child under twelve is generally considered to lack the capacity to make an informed decision regarding its health, how much weight will parents and guardians attach to views and wishes of the child? An Australian research study, which was recently conducted, indicated that some children preferred to communicate their views to a judge, without their parents' knowledge. S 31 of the Children's Act does not afford children this alternative and therefore out of fear, a child may not reveal to his or her parents how he or she truly feels about the proposed treatment or surgery. See Sloth-Nielsen "Seen and Heard? New Frontiers in Child Participation in Family Law Proceedings in South Africa" 2009 Speculum Juris: Special Issue: Family Law 118.

51 The inclusion of $\mathrm{S} 10$ can be viewed as South Africa's compliance with the duties placed on it by the UNCRC and ACRWC, by virtue of its status as a State Party to both instruments. See art 12(1) of the UNCRC and arts 4(2) and 7 of the ACRWC. Art 12 of the UNCRC has been acknowledged as giving the UNCRC a "soul", presumably because it "recognises that children are active legal subjects ..." See Davel "General Principles" in Davel and Skelton (eds) Commentary on the Children's Act 2-12, 2-14. See further Sloth-Nielsen 2009 Speculum Juris: Special Issue: Family Law $1 \mathrm{fn} 3$; and Sloth-Nielsen "Ratification of the United Nations Convention on the Rights of the Child: Some Implications for South African Law" 1995 SAJHR 401 410-411.

52 Children who are below the uniform age of consent for medical procedures should be afforded the opportunity to be heard and express their views. This was the view of Sachs $J$ 
When children reach the age of twelve, and provided they are of sufficient maturity, they are deemed to be competent enough to consent to medical treatment and surgical procedures. Originally, the age of consent for medical treatment was fourteen years of age, but this was reduced by the provisions in section 129 of the Children's Act.

Section 129(2) of the Children's Act states:

"A child may consent to his or her own medical treatment or to the medical treatment of his or her child if -

(a) the child is over the age of 12 years; and,

(b) the child is of sufficient maturity and has the mental capacity to understand the benefits, risks, social and other implications of the treatment."

With the introduction of the Children's Act, the age of consent for surgical operations was also lowered - this time from eighteen years of age to twelve years of age. ${ }^{54}$ The lowering of the age of consent has been described as "a welcome recognition of children's autonomy and evolving capacity." Section 129(3) provides:

"A child may consent to the performance of a surgical operation on him or her or his or her child if -

(a) the child is over the age of 12 years; and,

(b) the child is of sufficient maturity and has the mental capacity to understand the benefits, risks, social and other implications of the surgical operation; and,

(c) the child is duly assisted by his or her parent or guardian."

Although section 129(3) recognises that a child of twelve presumably has the capacity to consent to surgery, it requires that he or she still be duly assisted by a parent or guardian. ${ }^{56}$ In the event that the parent who needs to consent to surgery is still a minor him- or herself, he or she requires the assistance of his or her own parent or guardian to consent to the surgery. ${ }^{57}$ Should a parent or guardian refuse to duly assist the child when he or she (the child) consents to the surgery, the Minister of Social Development may consent to the surgical operation.

in Christian Education South Africa v Minister of Education 2000 (10) BCLR 1051 (CC) Sachs $\mathrm{J}$ asked in this case, why the views of the children who were liable to be punished had NOT been sought and placed before the court. Although different in nature, the concept is the same.

53 See s 39(4)(b) of the Child Care Act 74 of 1983.

54 See s 39(4)(a) of the Child Care Act 74 of 1983.

55 See Sloth-Nielsen in Davel and Skelton (eds) Commentary on the Children's Act 7-35.

56 One possible explanation why parental assistance is required in $s$ 129(3) can be found in SALC Discussion Paper 103. As a part of the discussion on the beginning and end of childhood, groups of children were asked what they believed they should be free to do. Many of the groups answered that children should be free to make their own decisions, but with guidance from adults. This answer provides support for the provision of parental assistance in s 129(3). See Review of the Child Care Act Discussion Paper 10367.

$57 \mathrm{~S} \mathrm{129(3)}$ and the regulations pertaining to $\mathrm{S} 129$ of the Act. In this situation, the child is referred to as a "child-parent". Kassan and Mahery in Boezaart (ed) Child Law in South Africa 208.

58 S 129(7)(a) of the Children's Act. See further s 129(7)(b)-(d). 
The uniform age of consent in regard to medical treatment and operations is now twelve years of age. ${ }^{59}$ The age limit for both medical treatment and surgery was lowered to twelve years of age, following the recommendations of the SALC. The SALC recommended that the age at which a child may consent to medical treatment be lowered to twelve years of age and that, until the age of eighteen is attained, a child cannot consent to an operation without parental assistance. ${ }^{60}$ The lowering of the age of consent followed comments received on certain recommendations made by the SALC, a consideration of South African law and policy and a review of law on this topic in other countries. ${ }^{61}$

As mentioned above, for purposes of a child consenting to medical treatment or surgical operations, two requirements must be complied with: age (twelve years and above) and maturity (sufficient maturity). In other words, the Children's Act uses what has been termed as a "combined approach" to determine a child's capacity to consent. ${ }^{62}$ This approach, despite being an improvement on the Child Care Act, ${ }^{63}$ does present a problem. The combined approach fails to factor in that some children below the age of twelve may in fact be of sufficient maturity to consent to medical treatment and or surgery. ${ }^{64}$ While it is generally presumed that children lack the maturity to make decisions (especially a decision as important as that relating to their health), holding that all children under the age of twelve are not sufficiently mature arguably restricts a child's autonomy unnecessarily. ${ }^{65}$ On this issue, Reynolds warns that "restricting children's autonomy unduly stunts their ability to judge and to make decisions for themselves and, therefore hampers their development as autonomous persons." ${ }^{\text {"6 }}$

In an attempt to address the problem of the combined approach, namely that a child who is of sufficient maturity but under the age of twelve cannot consent, a position similar to that adopted in the English case of Gillick $v$ West Norfolk and Wisbech Area Health Authority ${ }^{67}$ may be implemented. In

59 Compare s 39(4)(a)-(b) of the Child Care Act with s 129 of the Children's Act.

60 Review of the Child Care Act Discussion Paper 103470 and Review of the Child Care Act Report 139 par 10.3.1.

61 Review of the Child Care Act Discussion Paper 103 464-469.

62 See s 129 of the Children's Act. Alternatively, it can be said that the Children's Act uses a combination of factors to determine a child's capacity to consent to medical treatment or surgery.

63 Act 74 of 1983 . The Child Care Act followed an age-based approach to determine capacity to consent. Kassan and Mahery in Boezaart (ed) Child Law in South Africa 212.

64 Sloth-Nielsen in Davel and Skelton (eds) Commentary on the Children's Act 7-35.

65 See Reynolds "Consent and Competence in Paediatrics" 2007 International Journal of Children's Rights 503504 . Wald has also queried the existing assumptions on the capacities of children and asked whether it would not be necessary to determine if the current age restrictions in place make sense, in light of the different rate of maturity of children today compared to previous years.

66 See Reynolds 2007 International Journal of Children's Rights 504 as quoted in Kassan and Mahery in Boezaart (ed) Child Law in South Africa 214. See further S v M 2008 (3) SA 232 par 19, where it was held that "all children have the right to express themselves as independent social beings ... to themselves understand their bodies, minds and emotions and above all to learn .... and make choices in the wide social and moral world of adulthood".

671986 AC $112(\mathrm{HL})$. 
this case, the House of Lords confirmed that, where a child has "sufficient understanding and intelligence to understand the nature and implication of the proposed treatment", he or she is permitted to consent to medical treatment, and is known as "Gillick Competent", rendering parental consent unnecessary. ${ }^{68}$ The House of Lords did not restrict a child's capacity to an age limit but rather to their maturity. ${ }^{69}$ Should this approach not be suited to South African law, the recommendation that the wording of section 129 be changed to read "who by age or maturity", made by the Children's Rights Project and Local Government Project, could be adopted. ${ }^{70}$ Alternatively (and acknowledging that this would be a far more time consuming solution) where it appears that a child is of sufficient maturity, but has not reached the age of twelve, the matter may be brought before a panel or court for consideration. In other words, a case-by-case approach could be adopted, to consider whether or not a child not of age but who is of sufficient maturity should be allowed to consent to treatment or surgery. ${ }^{7}$

In addition to consent from parents or guardians, the superintendent of a hospital, or the person in charge when the superintendent is absent, may consent to the medical treatment of or surgical operation on a child. ${ }^{72}$ The superintendent may consent if:

"(a) the treatment or operation is necessary to preserve the life of the child or to save the child from serious or everlasting physical injury or disability; and,

(b) the need for the treatment or operation is so urgent that it cannot be deferred for the purpose of obtaining consent that would otherwise have been required."

Likewise, where a child unreasonably refuses to give his or her consent to medical treatment or surgical operations, the Minister of Social Development may consent to either the medical treatment or surgical operation on the child in question. ${ }^{73}$ The High Court or children's court may also consent to the medical treatment and surgical operation on a child "in all instances where another person that may give consent in terms of this section refuses or is unable to give such consent."

Section 129 concludes by stating:

"No parent, guardian or care-giver of a child may refuse to assist a child in terms of subsection (3) or withhold consent in terms of subsections (4) and (5) by reason only of religious or other beliefs, unless that parent or guardian can

681986 AC 112 (HL) 188-189 as quoted in Clark "'My Right to Refuse or Consent': The Meaning of Consent in Relation to Children and Medical Treatment" 2001 THRHR 605611.

69 See Kassan and Mahery in Boezaart (ed) Child Law in South Africa 214 for a discussion on the advantage of using an approach that focuses on maturity as opposed to age.

70 Review of the Child Care Act Report 141.

71 Freeman made the proposal that the legal capacity of a child should be determined on a case-by-case basis. See further Freeman The Rights and Wrongs of Children 46.

72 S 129(6) of the Children's Act.

S 129(8) of the Children's Act.

74 S 129(9) of the Children's Act. From the wording of s 129(9), it appears that another person refers to any of the persons mentioned in $\mathrm{s} 129$. 
show that there is a medically accepted alternative choice to the medical treatment or surgical operation concerned."

Section 129(10) can be viewed as a welcome development "in so far as a parent's religious beliefs may not trump the best interests of a child". ${ }^{76}$ Although the best interests of the child are of paramount importance, to say "that all competing rights must defer to the rights of children unless unjustifiable", is incorrect. ${ }^{77}$ This approach sits uncomfortably with the principle that "constitutional rights are mutually interrelated and interdependent and form a single constitutional value system". ${ }^{78}$ Therefore, should there be a conflict between the competing rights of a parent's right to religion and a child's right, such as the right to life, the matter requires a balancing of the competing rights. This approach was adopted by the court in the case of Hay $v B^{79}$ In this case the applicant (Dr Hay) approached the court, asking for an order allowing her to administer blood to the baby of a Jehovah's Witness couple, who refused the transfusion on religious grounds. The court granted the order, allowing the transfusion to take place. Jajhbay $\mathrm{J}$ held that, although the respondents' right to religion must be respected and that their concerns were understandable, these concerns were neither reasonable nor justifiable and their belief could therefore not outweigh the child's right to life. ${ }^{80}$

In addition to religion, section 129(10) states that a parent cannot refuse to assist a child or withhold consent by reason of "other beliefs". The inclusion of the words "other beliefs" extends the application of section 129(10) to traditional medicine ${ }^{81}$ thereby covering those South Africans who prefer to make use of traditional medicine as opposed to conventional medicine. For example, in 2006, the MEC for Social Development in Gauteng was petitioned by the Centre for Child Law to intervene and grant permission for a six-year-old girl to undergo brain surgery. At the time, the little girl had a cyst on her brain causing severe pressure which, if left unattended, would result in the child's death. The girl's father had been advised by a traditional healer to refuse the surgery. As the refusal of surgery was not in the best interests of the girl, it was ordered that surgery be performed. ${ }^{82}$ While it can be acknowledged that a person's beliefs are fundamental to the way they live and conduct themselves, this should clearly not impede a child's right to health and life.

S 129(10) Children's Act.

Sloth-Nielsen in Davel and Skelton (eds) Commentary on the Children's Act 7-36.

77 De Reuck v Director of Public Prosecutions (Witwatersrand Local Division) 2003 (3) SA 389 (W) par 10.

78 De Reuck v Director of Public Prosecutions (Witwatersrand Local Division) 2004 (1) SA 406 (CC) par 55

2003 (3) SA $492(\mathrm{~W})$

80 495D-E.

81 Sloth-Nielsen in Davel and Skelton (eds) Commentary on the Children's Act 7-36.

82 Venter "Girl (6) to have Brain Operation" 26 October 2006 Pretoria News, as reported by the Centre for Child Law. 
Furthermore, it must be highlighted that section 129(10) states that:

"[n]o parent, guardian or care-giver of a child may refuse to assist a child ... or withhold consent ... unless that parent or guardian can show that there is a medically accepted alternative choice to the medical treatment or surgical operation concerned."

This provision implies that, if a parent can successfully prove there is another feasible and accepted alternative to surgery, their refusal on religious grounds may be upheld. There are currently several alternative techniques that have been proposed as a substitute to blood transfusions, which will most certainly be viewed as a welcome provision amongst members of the Jehovah's Witness faith. ${ }^{83}$

\section{The distinction between medical treatment and surgical operations}

Section 129 of the Children's Act draws a distinction between medical treatment and surgical operations, for purposes of consent. The Act, like its predecessor, ${ }^{84}$ however, fails to define these two terms, despite the SALC recommendation that these terms be defined. ${ }^{85}$ While these terms are not defined in the Children's Act, "medical treatment" "is generally understood to include all procedures other than those requiring surgical intervention". This definition of medical treatment can be viewed as including blood transfusions, which have potential ramifications for members of the Jehovah's Witness faith. Members of this faith are known around the world for their consistent refusal of blood transfusions on religious grounds. ${ }^{86}$ Parents refuse this treatment both for themselves and their children. ${ }^{87}$ However, if medical treatment is seen to include all treatment that is nonsurgical, it means that a child who is over the age twelve (section 129(2) of the Children's Act) may consent to a blood transfusion, even if it is against the values of their belief and that of their parents. ${ }^{88}$

This interpretation of medical treatment, however, seems to be at odds with other interpretations of medical treatment, for the following reasons. Firstly, it would seem that the term "medical treatment" is used in a general sense and should therefore be seen as wide enough to include medical

${ }^{83}$ For more on these alternatives refer to Malherbe and Govindjee "A Question of Blood: Constitutional Perspectives on Decision-Making about Medical Treatment of Children of Jehovah's Witnesses" 2010 THRHR 61 67-70.

84 Child Care Act 74 of 1983.

85 Review of the Child Care Act Discussion Paper 103 470-471.

86 Malherbe and Govindjee 2010 THRHR 62. See further Malherbe Legal Issues Arising from the Medical Use of Blood on Children of Jehovah's Witnesses 1.

87 Malherbe Legal Issues Arising from the Medical Use of Blood on Children of Jehovah's Witnesses 1.

88 Medical treatment defined this way can also be seen as broad enough to include chemotherapy. The inclusion of chemotherapy here has potential ramifications for those who are parents of children with cancer. A child may be so ill that it no longer wants chemotherapy and it can therefore refuse to consent to the treatment when it is over twelve. 
operations. $^{89}$ Secondly, according to Bekink, to distinguish between treatment and operations amounts to a contradiction in terms and this is a matter which accordingly requires clarification. ${ }^{90}$ It must be noted that Bekink's definition of "medical treatment" includes medical operations. Therefore, what constitutes non-medical surgery needs to be determined. It is submitted that non-medical surgery includes plastic surgery, which is done to enhance the body and for no other reason. ${ }^{91}$ If this rationale is to be followed, it can be argued that, in terms of the wording of section 129 , assistance by parents or guardians for medical surgery will no longer be necessary, as it falls within the parameters of treatment, which only requires consent from a child.

\section{Best-interests-of-the-child-standard}

From the discussion above, it is acknowledged that, in terms of the law, children below the age of twelve or who are of insufficient maturity, are deemed to lack the capacity to consent to their own medical treatment or surgical operations. ${ }^{93}$ Section 129 of the Children's Act stipulates that, in these instances, a parent or guardian may consent to the proposed treatment or surgery on behalf of the child. As a parent or guardian, the decision that is made must reflect what will be in the best interests of the child. ${ }^{94}$

The duty or obligation that a parent has to act in the best interests of the child can be inferred from several sections of law. Section 28(2) of the Constitution clearly states that best interests of the child are of paramount importance in all matters. ${ }^{95}$ Furthermore, section $28(1)$ (b) of the Constitution guarantees every child the right to parental care. This right, when read together with the definition of care in the Children's Act, extends to include "generally ensuring that the best interests of the child are the paramount concern in all matters affecting the child". 96 Therefore, a parent has the duty to ensure that he or she is acting in the best interests of their child in matters pertaining to the health of the child.

89 Bekink "Parental Religious Freedom and the Rights and Best Interests of Children 2003 THRHR 246 259. See further Bekink "Striking a Balance between Parental Religious Freedom and the Rights and Best Interests of Children" in LØdrup and Modvar (eds) Family Life and Human Rights Papers presented at the $11^{\text {th }}$ World Conference of the International Society of Family Law (2004) 5973.

90 Bekink 2003 THRHR 259.

91 Most persons who undergo plastic surgery, have the surgery for the purpose of enhancing their looks. There are some procedures which are done for medical purposes. Such procedures would therefore be classified as medical operations and would fall under medical treatment.

92 If this interpretation is to be followed, it means that parents will be required only to consent to operations involving plastic surgery.

93 See s 129(4) and (5) of the Children's Act.

$94 \mathrm{~S} 28(2)$ of the Constitution.

95 This section, as observed, complies with both international and regional law. See art 3 of the UNCRC and art 4 of the ACRWC.

96 S 1 of the Children's Act. See further Heaton SA Family Law 284. 
Furthermore, section 9 of the Children's Act states that "[i]n all matters concerning the care, protection and well-being of a child the standard that the child's best interest is of paramount importance, must be applied". In that decisions relating to health concern the care and well-being of children, section 7 of the Children's Act must be applied. ${ }^{97}$ Unlike section 28(2) of the Constitution, section 7 of the Children's Act provides a list of factors that must be taken into consideration when determining what is in the best interests of a child. ${ }^{98}$

Prior to the enactment of the Children's Act, the best interests of a child were generally determined by utilising the list of factors provided for by King $\mathrm{J}$ in the case of McCall $v$ McCall. ${ }^{99}$ This case represents the first time that a comprehensive list of factors was provided according to which a court could refer in order to determine the best interests of a child. ${ }^{100}$ This list of factors represented what King $\mathrm{J}$ explained as being the sort of factors the court should take into account when deciding custody issues. ${ }^{101}$ Therefore, when the SALC was tasked with reviewing child-care legislation in South Africa, it was convinced that the courts and other users of the new children's statute were in desperate need of understanding what exactly was meant by the words, "a decision or action must be in the best interests of a child". ${ }^{102}$ The recommendation put forward by the Commission was that guidelines needed to be set in place, which resulted in the inclusion of section $7(1)(a)-(n) .{ }^{103}$

$97 \quad S 7(1)$ states "Whenever a provision of this Act requires the best interests of the child standard to be applied, the following factors must be taken into consideration where relevant ..."

98 Provision for the best interests of the child in the Children's Act can be deemed as South Africa complying with the duties imposed on it by the UNCRC and the ACRWC. As a State Party to both instruments, Government is required to take measures, that will allow for the implementation of the rights in these respective instruments into national law. See chapter 2 and art 3 of the UNCRC and art 4 of the ACRWC. In international law, the best interests of a child is described as a primary consideration. In South African law, the standard was raised from a primary consideration to being of paramount importance. According to comments made on the Children's Act, "paramount" means "supreme or of utmost importance". Bosman-Sadie and Corrie Practical Approach to the Children's Act (2010) 23.

991994 (3) SA 201 (C). There had been attempts before this case to create a list, namely in Fletcher $v$ Fletcher 1948 (1) SA 130 (A) and French v French 1971 (4) SA 298 (W), but these factors were not as comprehensive as the factors in McCall. See further Domingo 2006 Annual Survey of South African Law 142.

100 Palmer "The Best Interests Criterion: An Overview of its Application in Custody Decisions Relating to Divorce in the Period 1985-1995" in Keightley (ed) Children's Rights (1996) 100-101.

101 The case of Ngobeni $v$ Ngobeni TPD 20-02-2008 case no 39972/05 lends itself to this interpretation and opinion as well.

102 Review of the Child Care Act Discussion Paper 10385.

103 Review of the Child Care Act Discussion Paper 103 85. The influence behind the drafting and inclusion of this list of factors can be traced back to s 68F of the Australian Family Law Act 1975. This particular section attempts to give guidance to Australian Courts in determining what is in a child's best interests. Following reference to this section in Discussion Paper 103, the Commission recommended that regard must be had to a list of criteria in determining the best interests of a child and that such a list should be included in the new children's statute, hence the inclusion of s 7(1) of the Children's Act. See Review of the Child Care Act Discussion Paper 10384. 
The provision of this list of factors for the determination of the best interests of the child can be seen as a welcome development in law due to its wide application. ${ }^{104}$ However, this is a closed list of factors, allowing the court no possibility for consideration of alternative factors. ${ }^{105}$ The fact that section 7(1) is a closed list, allows for the argument to be made that it is a "pre-determined formula". The Constitutional Court had previously held that applying a pre-determined formula is contrary to the best interests of the child. ${ }^{106}$ As a way of possibly overcoming this problem, the courts could consider "all relevant factors" to determine the best interests of the child. ${ }^{107}$ Theoretically, this would mean that courts would be able to consider any factor they deem necessary, in addition to the factors listed in section 7(1).

\section{Choice on Termination of Pregnancy Act}

While section 129 of the Children's Act restricts a child's right to consent with respect to surgical operations, it in no way limits a young girl's right to consent to the termination of her pregnancy. ${ }^{108}$ Section 5(1) of CoToPA states that the termination of a pregnancy may take place only with the informed consent of the pregnant woman. Section 5(2) of the Act supports section $5(1)$ by stating that "no consent other than that of the pregnant woman is required for the termination of a pregnancy." 109 For purposes of this Act, a woman is defined as "any female person of any age."110 By virtue of this definition, section 5(1)-(2) of the Act and section 129(1) of the Children's Act, read together, a woman (any female of any age) including a

104 See $S$ v M supra par 12 where it was held that the scope of the best-interests test had been greatly enlarged and was no longer limited to mostly custody and maintenance cases.

105 It can be inferred that $\mathrm{7(1)}$ is a closed list, in view of the fact that it lacks provision for the consideration of any other factor which may be relevant. Although being a closed list, it is the opinion of some that "it is unthinkable that a court would refuse to take any other factor into account if it were relevant in a particular case". If the courts were to refuse a consideration of factors additional to $s 7(1)$ to determine the best interests of the child, it would most assuredly contravene s 28(2) of the Constitution, as it "would not render the child's best interests of paramount importance." See Heaton SA Family Law 165.

106 S v M supra par 24

107 Factor $(\mathrm{m})$ of the list in McCall $v$ McCall supra allows the court to consider "any other factor which is relevant ..."

108 S 129(1) of the Children's Act states "[s]ubject to section 5(2) of the Choice on Termination of Pregnancy Act, 1996 (Act No.92 of 1996), a child may be subjected to medical treatment or a surgical operation ..." When s 129 was first made public, it was assumed that the age of consent applied to the termination of pregnancies as well. This interpretation meant that girls under the age of twelve would not be able to consent to an abortion and those who were over the age of twelve would require parental assistance. However, from the wording of $s$ 129(1), it is clear that the age of consent does not apply to termination of pregnancies. Kassan and Mahery in Boezaart (ed) Child Law in South Africa 214.

109 Informed consent must be given in order for the termination of pregnancy to take place. Informed consent accordingly means that girl patients must: (i) have knowledge of the nature and extent of the harm associated with a termination of pregnancy; (ii) appreciate and understand the consequences of a termination of pregnancy, and (iii) agree to undergo the termination of pregnancy; furthermore (iv) her agreement must be comprehensive and extend to all the consequences of the termination of pregnancy. See McQuoid-Mason "Some Consent and Confidentiality Issues Regarding the Application of the Choice on Termination of Pregnancy Act to Girl-Children" 20103 SAJBL 1213.

110 S 1 (xi) of CoToPA. 
girl has the right to consent to the termination of her pregnancy and requires no additional support or consent. ${ }^{111}$

Having said that only the consent of the woman is required for the termination of pregnancy, there is one notable exception. According to section 5(4), someone other than the woman, such as a spouse or legal guardian ${ }^{112}$ may consent to the termination of pregnancy in the case where a woman is:

"(a) severely mentally disabled to such an extent that she is completely incapable of understanding and appreciating the nature or consequences of a termination of her pregnancy; or,

(b) in a state of continuous unconsciousness and there is no reasonable prospect that she will regain consciousness in time to request and to consent to the termination of her pregnancy in terms of section 2 , her pregnancy may be terminated during the first 12 weeks of the gestation period, or from the 13th up to and including the 20th week of the gestation period on the grounds set out in section 2(1)(b)."

Although parental consent is needed for treatment or surgical operations on children below twelve years of age, it is clear from the wording of CoToPA that a girl child of any age may consent to the termination of her pregnancy. This ability to consent extends to any medical treatment associated with the termination of pregnancy, provided she has given her informed consent and is capable of doing so.

\section{Existing national-health framework}

On 28 April 2010, the President of South Africa held that sections 55, 56, 68 and 93(1) of the NHA would become operational from 17 May 2010. ${ }^{114}$ The operation of these sections replaces the out-dated sections in the Human Tissues Act (HTA). ${ }^{115}$ Sections 55 and 56 (contained in chapter 8 of this Act) regulate the removal and use of tissue, ${ }^{116}$ blood, blood products ${ }^{117}$ or gametes ${ }^{118}$ from living persons. ${ }^{119}$

111 S 5(3) of CoToPA states that the medical practitioner or registered midwife shall advise the minor to consult with relatives or friends before undergoing the procedure, but they cannot refuse to perform the abortion should the minor refuse to seek counsel. CoToPA fails to make provision for a girl who was forced or coerced into aborting her foetus.

112 A pregnancy may be terminated in terms of s 5(4) at the "request of and with the consent of her natural guardian, spouse or legal guardian, as the case may be; or if such persons cannot be found, upon the request and with the consent of her curator personae".

113 McQuoid-Mason 20103 SAJBL 13.

114 Proc R 20 in GG 33187 of 2010-05-14. Presently chapter 8 which is due to replace the entire HTA is not operational with the exception of ss 55,56 and 68 . S 93(1) was also deemed to be operational from 17 May 2010, in so far as it repealed s 23(b) of the HTA. S 53 of the NHA is also operational; however, it was already operational from 30 June 2008 See Proc R 22 in GG 31187 of 2008-06-27. The NHA is operational with the exception of chapter 6 and certain sections of chapter 8 of the Act.

115 Act 65 of 1983. S 55 of the NHA replaced s 18 of the HTA and s 56 of the NHA replaced s 19(i)-(iv) of the HTA.

116 Tissue means "human tissue, and includes flesh, bone, a gland; an organ, skin, bone marrow or body fluid, but excludes blood or a gamete". See s 1 of NHA. 
Section 55 of the NHA states:

"A person may not remove tissue, blood, a blood product or gametes from the body of another living person for the purpose referred to in section 56 unless it is done -

(a) with the written consent of the person from whom the tissue, blood, blood product or gametes are removed granted in the prescribed manner; and,

(b) in accordance with prescribed conditions."

Section 55 requires the written consent of the person from whom the tissue, blood and blood products are to be removed. The removal of tissue, blood and blood products amounts to a medical procedure. Therefore, although the section requires the consent of the person from whom the products are to be removed, where the removal pertains to a child, the rules of section 129 of the Children's Act apply. In other words, where the child is below the age of twelve, it is accepted that his or her parent or guardian may consent to the removal of tissue, blood and blood products. ${ }^{120}$ Should the child be over the age of twelve and be of sufficient maturity, it is the child who consents to the removal of tissue or blood, but with the assistance of a parent or guardian. ${ }^{121}$

Section 55 further requires that, in addition to obtaining written consent, the removal of blood, blood products and tissue may be done only in accordance with prescribed conditions. According to section 1 of the NHA, "prescribed" means prescribed by regulation under section 90 . Section 90 states that "[t]he Minister, after consultation with the National Health Council, may make regulations regarding anything which may or must be prescribed in terms of this Act." However, only certain parts of the Act were implemented with immediate effect, and as a result of new medical development and research on human subjects, a vacuum soon developed in our law.

In May 2010, the Minister of Health, after consultation with the National Health Council, passed Regulations Relating to the Withdrawal of Blood from a Living Person for Testing. ${ }^{122}$ Where provisions previously contained in the

117 S 1 of the National Health Act defines "blood product" as meaning "any product derived or produced from blood, including circulating progenitor cells, bone marrow progenitor cells and umbilical cord progenitor cells". The definition of a blood product in s 1 of the NHA is more comprehensive in its definition of blood product than $s 1$ of the HTA. S 1 of the HTA defines a blood product as "any product derived or produced from blood".

118 A "gamete" means "either of the two generative cells essential for human reproduction" according to $\mathrm{s} 1$.

119 The regulation of the removal of blood, blood products and tissue is important for the discussion on "benefactor children" and "saviour siblings" that follows in the subsequent contribution. This article will show that tissue, blood and blood products are commonly needed to cure diseases when medicinal treatment or conventional treatment fails.

120 That a parent can consent to the removal of tissue and other bodily components is worrisome, especially if the child happens to be a "benefactor child" or "saviour sibling".

$121 \mathrm{~S} \mathrm{18}(\mathrm{b})$ of the HTA required parents or guardians to give consent where a child was still a minor, thus strengthening the statement that the conditions employed in s 129(3) and (5) must be invoked in the application of s 55 of the NHA. Ss 55 and 56 are extremely important to the discussion on "benefactor children" and "saviour siblings".

122 This regulation became operational on 17 May 2010. 
HTA were excluded from those of the NHA, these were now included in the regulations. ${ }^{123}$ These include provisions concerning instances as follows:

(a) tissue donation by living persons;

(b) organ transplantations into non-South African citizens and nonpermanent residents;

(c) donations of human bodies and tissue of deceased persons;

(d) allocation and use of human organs of deceased persons;

(e) exclusivity of rights in donations; and

(f) confidentiality and publicity regarding donations."

From the wording of these regulations, there are certain conditions mentioned that must be met in order for tissue, blood and blood products to be removed or withdrawn. However, the regulations are not extensive and still leave the reader unsure as to what conditions must be met before the withdrawal or removal takes place. ${ }^{124}$ The Act for example makes no provision as to who may consent to the donation of human tissue in the event that the donor is alive. The regulations make provision for this by stating that tissue, blood and gametes may not be removed from the body without the written consent of the donor where the donor is above 18 years of age, and where the donor is less than 18 years old, the parents or guardians must grant such written consent. ${ }^{125}$ Tissue and gametes that are not replaceable by natural process in the instance of a donor below 18 years of age may not be donated. ${ }^{126}$ The regulations make further provisions as to whom the tissue, blood, blood product or gamete may be provided to as follows:

(i) hospitals;

(ii) universities or universities of technology;

(iii) authorised institutions;

(iv) medical practitioners or dentists; or,

(v) a tissue bank or any person who requires therapy in which such tissue can be used. ${ }^{127}$

Section 55 provides the requirements that must be met before blood, blood products and tissue may be removed for the purposes in section 56 . Therefore, the two sections must be read together to have full understanding of the provisions in each.

123 McQuoid-Mason "Human Tissue and Organ Transplant Provisions: Chapter 8 of the National Health Act and Its Regulations, in Effect from March 2012 - What Doctors Must Know" 2012 102(9) South African Medical Journal 733-735.

124 See Regulations Relating to the Withdrawal of Blood from a Living Person for Testing GN R 401 in GG 33188 of 2010-05-14.

125 Regulation 2 of the Regulations Regarding the General Control of Human Bodies, Tissue, Blood, Blood Products and Gametes in Government Notice R180 of GG No. 35099 201203-02.

126 S 56(2) of the National Health Act 61 of 1983.

127 Regulation 4 of the Regulation cited in above fn 140. 


\section{Section 56 states:}

"(1) A person may use tissue or gametes removed or blood or a blood product withdrawn from a living person only for such medical or dental purposes as may be prescribed.

(2) (a) Subject to paragraph ...

(b) the following tissue, blood, blood products or gametes may not be removed or withdrawn from a living person for any purpose contemplated in subsection (1):

(i) Tissue, blood, a blood product or a gamete from a person who is mentally ill within the meaning of the Mental Health Care Act, 2002 (Act No. 17 of 2002);

(ii) tissue which is not replaceable by natural processes from a person younger than 18 years:

(iii) a gamete from a person younger than 18 years; or

(iv) placenta, embryonic or foetal tissue, stem cells and umbilical cord, excluding umbilical cord progenitor cells.

(c) The Minister may authorise the removal or withdrawal of tissue, blood, a blood product or gametes contemplated in paragraph (a) and may impose any condition which may be necessary in respect of such removal or withdrawal."

Section 56(1) states that a person may use blood, blood products, tissue and/or gametes "withdrawn from a living person only for such medical or dental purposes as may be prescribed". As noted above, "prescribed" means prescribed by regulation under section 90 . The regulations enacted by the Minister of Health in May 2010, namely Regulations Relating to the Withdrawal of Blood from a Living Person for Testing, apply not only to section 55 but to section 56 as well. However, the various regulations making up the Regulations Relating to the Withdrawal of Blood from a Living Person for Testing fail to list the medical and dental purposes for which blood, blood products and tissue may be withdrawn or removed as referred to in section 56 . This has resulted in there being a lack of clarity as to which procedures constitute the purposes where blood, blood products and tissue may be removed or used. ${ }^{129}$ As there exists ambiguity as to which medical and dental purposes will allow for tissue and blood to be removed, it is particularly uncertain whether or not South African law regulates the removal of cells and tissues from "saviour siblings". ${ }^{130}$ A "saviour sibling" may be defined as a child who was conceived and selected as an embryo by his or her parents, specifically to be an organ or tissue donor for an ill sibling. The legal position of saviour siblings and "benefactor children" (children who are not born as the result of genetic engineering but who serve a similar purpose

128 The wording of $\mathrm{s} 56$ of the NHA has given rise to many concerns about academic freedom and the freedom of scientific research, which are both entrenched in $s$ 16(1)(d) of the Constitution. See Swanepoel 2010 THRHR 9. Furthermore, the wording of s 56(2)(a)(iv) appears to create a loophole in the law. By virtue of using the words "living person", it can be argued that while still a foetus in the womb, it is not considered as a living being, which could potentially allow for procedures such as the removal of stem cells to take place in utero.

129 The Act fails to define prescribed conditions in s 55 .

130 The Regulations Relating to Human Stem Cells GN R 376 in GG 29840 of 2007-05-04 regulates the use of stem cells for very specific purposes which, from a lay person's understanding, does not appear to include stem cells taken from "saviour siblings". 
of being potential life-saving donors to an ill sibling) is afforded detailed consideration in a subsequent contribution, where provisions of the National Health Act, international, foreign, regional and other national laws are applied in order to determine the effects of scientific advancement in genetics on these categories of children's rights to bodily integrity and autonomy. Although a comprehensive analysis of chapter 8 of the NHA has not been carried out in this contribution, it may be noted, at the very least, that "chapter 8 of the National Health Act is confusing and incomplete."

\section{CONCLUSION}

Recent developments in children's law have seen the age of consent for medical treatment and surgery being lowered. Unlike the Child Care Act, ${ }^{132}$ where two distinct age limits were set in place, ${ }^{133}$ the newly operational Children's Act has seen the age of consent lowered to a uniform age of twelve. ${ }^{134}$ The consequence of this is that children twelve years and older, are considered capable by law, to consent to or refuse any proposed medical treatment or surgery. Therefore, parents are now able to consent to treatment or surgery only on a child below the age of twelve. Although a child under twelve is not actively making the decision, he or she does have the right to participate in the making of the decision, and can therefore voice any concerns about the proposed treatment. ${ }^{13}$

Age alone does not give a child the capacity to consent. The Children's Act makes provision for a combined approach, which means that for a child to have the capacity to consent, it must meet two requirements. These requirements are age and maturity. Should a child fail to meet either of these requirements, it will be regarded as lacking capacity and will be treated in the same manner as a child under the age of twelve.

There are some who believe that the new age limit is too low, as a child is regarded as lacking capacity at this age. ${ }^{136}$ There are others, though, who believe that the age limit should be removed altogether and that only a mature approach (where only the maturity of the child is used to determine capacity) should be adopted. ${ }^{137}$ This submission is made, based on the

\footnotetext{
Pepper "Cell-based Therapy - Navigating Troubled Waters" 20105 SAMJ 286288.

32 Act 74 of 1983.

133 See s 39(4). The age limit was lowered from fourteen years of age for consenting to medical treatment and eighteen years of age for surgery.

134 Act 38 of 2005. It was decided, following the recommendations of the SALC, that the recognised age for consenting to medical treatment or surgery be lowered to a uniform age of 12. The SALC made this particular recommendation only after receiving comments on certain recommendations made by the SALC, as well as a consideration of South African law and policy and a review of law on this topic in other countries. See Review of the Child Care Act Discussion Paper 103 464-469.

135 See s 31 of the Children's Act.

136 Sloth-Nielsen in Davel and Skelton (eds) Commentary on the Children's Act 7-35.

137 See the discussion under heading 521 as well as the case of Gillick $v$ West Norfolk and Wisbech Area Health Authority 1986 AC 112 (HL).
} 
argument that the age limit is arbitrary and undermines and restricts autonomy. ${ }^{138}$

It must be noted that the age restrictions in section 129 do not affect a woman's right to have an abortion. The initial interpretation of the age provisions in section 129 of the Children's Act led many to believe that the age restrictions also applied to the termination of pregnancies. ${ }^{139}$ However, section 129(1) rectifies this misinterpretation, by specifically referring to section 5(2) of CoToPA, which clearly states that only the consent of the woman (or girl) is needed for the termination of pregnancy.

In terms of the national health legislation discussed, the provisions of the $\mathrm{NHA}$ are bold, but leave much to be desired as a result of vagueness and incompleteness. The aim of the Act and its Regulations was to provide a solution to deal with the existing vacuum in our law. However, medical advancement moving at the rate that it does make it apparent that it remains a challenge for the law of South Africa to stay in touch with innovations in the medical realm. Furthermore certain omissions in the legislation compounded by inaccuracies in the regulations ${ }^{141}$ have left the law lagging behind the rapid developments in medical science.

Notwithstanding the discussion above with reference to who consents to the treatment or surgery on a child, it must be remembered that, in any matter, the best interests of the child are of paramount importance. Not only does the Constitution require this, but so too does the Children's Act. ${ }^{142}$ In all of this, the position of certain categories of children remains precarious. The thrust of the contribution which follows this one focuses directly on the dilemma facing "saviour siblings" and "benefactor children" in South Africa.

138 See Kassan and Mahery in Boezaart (ed) Child Law in South Africa 214; and Reynolds 2007 International Journal of Children's Rights 504.

139 Kassan and Mahery in Boezaart (ed) Child Law in South Africa 214.

140 A woman is defined as a female of any age for purposes of CoToPA. See s 1(xi) CoToPA.

141 Relating to the use of human biological material.

142 See ss 7 and 9 of the Children's Act. 